mag. Jasmina Mirčeva

Andragoški center Slovenije

\title{
IZOBRAŽEVANJE ZAPOSLENIH V TRANZICIJSKEM GOSPODARSTVU
}

\section{Inovativni in razvojni modeli organiziranosti izobraževanja $v$ organizacijah}

V

mnogih vzhodno- in srednjeevropskih državah so se že pred letom 1989 pojavile težnje po posodabljanju in celo bolj radikalnih spremembah $\mathrm{v}$ sistemih izobraževanja ter usposabljanja zaposlenih $\mathrm{v}$ gospodarstvu, pri nekaterih pa so te usmeritve segale celo v šestdeseta leta. Toda zaradi rigidnosti gospodarskega in političnega sistema ter ideološkega monizma in enostranskosti razvoja $\mathrm{v}$ državah socialističnega bloka napredne in inovacijske usmeritve na splošno niso bile širše podprte. Po dolgih letih neuspešnega delovanja in razpadu gospodarskega ter političnega sistema in družbenega reda $\mathrm{v} d r-$ žavah Vzhodne in Srednje Evrope so se pojavili novi izzivi in gibanja v organiziranosti gospodarstva ter tudi sistemov izobraževanja in usposabljanja zaposlenih $\mathrm{v}$ njem. Ti izzivi so bili izraz že poglobljenih procesov preoblikovanja $\mathrm{v}$ svetu, pa tudi notranjih sprememb oziroma procesov gospodarske evolucije. Najbolj žgoči globalni dejavniki, ki so zahtevali preoblikovanje organiziranosti izobraževanja in usposabljanja zaposlenih v gospodarstvu, so bili: družbeni (prehod iz industrijske družbe $\mathrm{k}$ informacijski, prostorska globalizacija in večja izbira življenjskih slogov), politični (demokratizacija in pluralizacija politike, več odprtosti in sodelovanje $\mathrm{z}$ zahodnimi državami in odpira- nje prostora za nove mednarodne povezave in institucije), ekonomski (potreba po oblikovanju enotnega evropskega trga in valute, bolj odprto mednarodno in ekonomsko sodelovanje, privatizacija, prosti trg in gospodarsko restrukturiranje, večja mobilnost delovne sile in naraščanje kvalifikacijskih zahtev zaposlenih), tehnološki (tehnološko-tehnični razvoj, ki po eni strani ponuja učinkovitejše rešitve pri delu, po drugi strani pa

Globalizacija in notranji transformacijski procesi v gospodarstvu, ki so tudi podlaga napovedi za razvoj v prihodnosti, zahtevajo nujnost nenehnega usposabljanja in izpopolnjevanja zaposlenih. To pomeni, da postajajo večkratna kvalifikacija, prekvalifikacija in nenehno izobraževanje ter usposablianje delovne sile nujna in redna vsakdanja praksa. Po mnenju znanega teoretika sodobnega managementa P. Druckerja (1993) je znanje danes temelini generator tekmovalnosti in gospodarske uspešnosti. To oskrbuje gospodarstvo z najpomembnejšimi sredstvi za proizvodnjo, zato predlaga Drucker celo zamenjavo Marxove teorije o vrednosti dela $\mathrm{z}$ novo teorijo o vrednosti znanja. 
zahteva večjo usposobljenost ter znanje njenih uporabnikov) in demografski dejavniki (slaba nataliteta, podaljšana življenjska doba, spreminjanje razmerja med aktivnim in neaktivnim prebivalstvom ipd.).

Notranji transformacijski procesi ali procesi gospodarske preobrazbe, ki zahtevajo novo organiziranost sistema izobraževanja in usposabljanja zaposlenih, se, po mnenju Offermana in Gowinga (Titmus, 1989), izražajo predvsem $\mathrm{z}$ razvojem in ohranjanjem kompetitivnosti $\mathrm{v}$ gospodarstvu, naraščanjem zahtev $\mathrm{v}$ podjetjih po racionalnejšem upravljanju človeškega kapitala in izražanjem potreb po optimiranju organizacijske sestave podjetij, učinkovitejši rabi sodobne tehnologije in navezovanju stikov $\mathrm{z}$ delovnim okoljem. Notranje transformacijske procese povzročajo tudi gospodarska nestabilnost, turbulence $\mathrm{v}$ okolju ter večje možnosti za razvijanje oscilacije in celo za naglo gospodarsko recesijo in padec.

Tudi slovensko gospodarstvo je eno tistih, ki pod vplivom zunanjih in notranjih transformacijskih procesov doživlja korenite strukturne spremembe. Znano je, da je po ustaljenih kazalnikih gospodarske razvitosti Slovenija srednje razvita država na prehodu. Njeno gospodarstvo je bilo med letoma 1981 in 1992 in še posebej po osamosvojitvi države ter razpadu jugoslovanskega trga $\mathrm{v}$ določeni strukturni krizi. Kljub temu pa kažejo danes novejši kazalci (hitro prestrukturiranje gospodarstva, lastninjenje, proizvodna rast, preusmerjanje izvoza predvsem $\mathrm{v}$ zahodno- in srednjeevropske države ipd.) hitrejši izhod iz kriznih razmer (Približevanje Evropi - rast, konkurenčnost in integracije, 1995). Res je, da je v Agendi 2000 Evropska zveza pozitivno ocenila gospodarske, socialne, in politično-demokratične dosežke v Sloveniji, in to velja tudi za njene razvojne usmeritve. Še posebno v primerjavi z državami, ki so bile novembra 1997 pogojno do- ločene za prvi krog včlanjenja v Evropsko zvezo, ima Slovenija precej ugodnejše startno-razvojne parametre in stopnje (GDP 10.000 USD p. c., devizne rezerve 4,3 milijona USD, 70 odstotkov izvoza v EZ, 14-odstotno stopnjo brezposelnosti, 8,9-odstotno stopnjo inflacije itn.). Toda v Agendi je bilo ravno tako veliko pripomb in pobud za spremembe na gospodarskem področju, te pa so posredno ali neposredno ve-

Izobraževanje zapo-
slenih v Sloveniji ni
prilagojeno razvoj-
nim gospodarskim
usmeritvam.
zane tudi na izobraževanje in usposabljanje zaposlenih (Agenda, 1997). Tudi nekatere druge analize in raziskave (Medveš, Z., Muršak, J. 1992, 1993) kažejo, da zdajšnje stanje in organiziranost izobraževanja in usposabljanja zaposlenih nista zadosti prilagojena potrebam in razvojnim usmeritvam $\mathrm{v}$ gospodarstvu. To je usmerjalo $\mathrm{k}$ preučevanju potreb in organiziranosti izobraževanja za potrebe zaposlenih $\mathrm{v}$ gospodarstvu, ki se izražajo in zadovoljujejo $\mathrm{v}$ samih podjetjih in tudi zunaj njih oziroma $\mathrm{v}$ širšem družbenem okolju.

\section{RAZISKOVALNI PRISTOP}

Ker sta zdajšnje stanje in organiziranost izobraževanja in usposabljanja predmet kritike in nezadovoljstva, smo na podlagi analiz poiskali in predložili mogoče modele organiziranosti izobraževanja, ki so iz zornega kota podjetij različne velikosti, lastninskega statusa, panoge, regionalne pripadnosti in drugih lastnosti najbolj ustrezale zdajšnjemu razvoju in smernicam gospodarstva. Te smernice pa so gotovo upoštevale tudi potrebe in mnenja višjih ravni urejanja izobraževanja zaposlenih $\mathrm{v}$ podjetjih (združenja, zbornice, panoge) ali širše $v$ gospodarstvu in $\mathrm{v}$ državi v celoti.

Dejstvo je, da natančnih modelov izobraže- 
vanja/usposabljanja zaposlenih v prihodnosti, ni mogoče ponuditi, saj je težko določiti, kakšni bodo nadaljnji razvoj in strukturne spremembe gospodarskih subjektov. Jasno je tudi, da bi bile ponujene smernice uspešne le, če bi bile odprte in pripravljene sprejemati izzive novega časa. Kljub temu pa menimo, da razvojna gibanja na tem področju ne morejo potekati spontano, temveč načrtno in premišljeno, pobude pa morajo prihajati $z$ vrha in tudi $z$ dna.

Preučevanje te problematike smo dopolnili z analizo vsebine nekaterih primarnih in sekundarnih virov, teoretičnih in raziskovalnih. Za zbiranje stališč in mnenj subjektov na makro- in mikroravni odločanja smo $\mathrm{v}$ okviru empiričnega dela raziskave uporabili predvsem anketno metodo, s katero smo pridobili mnenja organizatorjev izobraževalnih dejavnosti $\mathrm{v}$ podjetjih, in metodo intervjuvanja, ki je zagotovila mnenja strokovnjakov glede ustvarjanja izobraževalne politike na ravni države, sindikalnih organizacij, gospodarskih združenj in raziskovalnih institucij s področja izobraževanja. Za ugotavljanje stanja in oblikovanje modelov smo uporabili nekatere statistične vire. $\mathrm{Na}$ podlagi tega so bili oblikovani nekateri modeli in predlogi za nadaljnjo organiziranost izobraževanja ter usposabljanja zaposlenih, ki na podlagi raziskave najbolj ustrezajo zdajšnjemu razvoju gospodarstva in širši družbeni ureditvi. Raziskava je bila opravljena v letu 1996/1997. Empirične postopke smo izvedli na podlagi vzorca 230 slovenskih podjetij.

\section{TEMELJNE UGOTOVITVE}

Na začetku smo skušali preučiti usklajenost med stanjem izobraževanja in potrebami po izobraževanju v gospodarstvu. $\mathrm{V}$ ta namen smo primerjali razlike med potrebami po izobraževanju zaposlenih $\mathrm{v}$ podjetjih in mo- žnostmi za uresničevanje teh potreb. Izsledke raziskovanja lahko strnemo $\mathrm{v}$ naslednje skupne ugotovitve:

Izidi raziskave so globalno pokazali, da se v podjer ih v skladu s sodobnimi potrebami v gospodarstvu uveljavljajo ali upoštevajo predvsem programi usposablianja in izpopolnjevanja za delo. Med temi prevladujejo: usposablianje in izpopolnjevanje po zakonskih predpisih, izpopolnjevanje in usposablianje za prenovo temelinega poklicnega in strokovnega znanja, se posebej za zahtevnejša in najzahtevnejša dela, ter usposabljanje in izpopolnjevanje za zagotovitev kakovosti. Nekoliko manj navajajo programe za pridobitev izobrazbe. Med temi prevladujejo programi za pridobitev izobrazbe na IV. V. in VI. stopnji. Obravnavana podjetja deloma ali le izjemona upośtevajo potrebe po splošnem izobraževanju (programi neformalnega splośnega izobraževanja in programi za državljansko ter politično vzgojo), ker iih v zdajšnjh gospodarskih razmerah štejejo za manj aktualne.

$\mathrm{V}$ polovici tega desetletja se je v primerjavi $\mathrm{z}$ obdobjem pred osamosvojitvijo Slovenije pri zadovoljevanju potreb po izobraževanju in usposabljanju nekoliko povečal delež programov izpopolnjevanja in usposabljanja za delo, na nekaterih ravneh pa so se zmanjšale ali ohranile potrebe po pridobitvi izobrazbe. Razvojne težnje čedalje bolj izražajo naraščanje potreb po izpopolnjevanju za delo, predvsem po usposabljanju za razvoj in zagotovitev kakovosti, vodenje in poslovodenje, izobraževanje $v$ tujih jezikih. Opaža pa se tudi nekoliko večje zanimanje za programe za pridobitev izobrazbe. Med temi bodo $\mathrm{v}$ prihodnje najaktualnejši programi po pridobitvi izobrazbe na višje- in visokošolski stopnji in deloma pridobivanje specializacij in magisterija. Splošnoizobraže- 


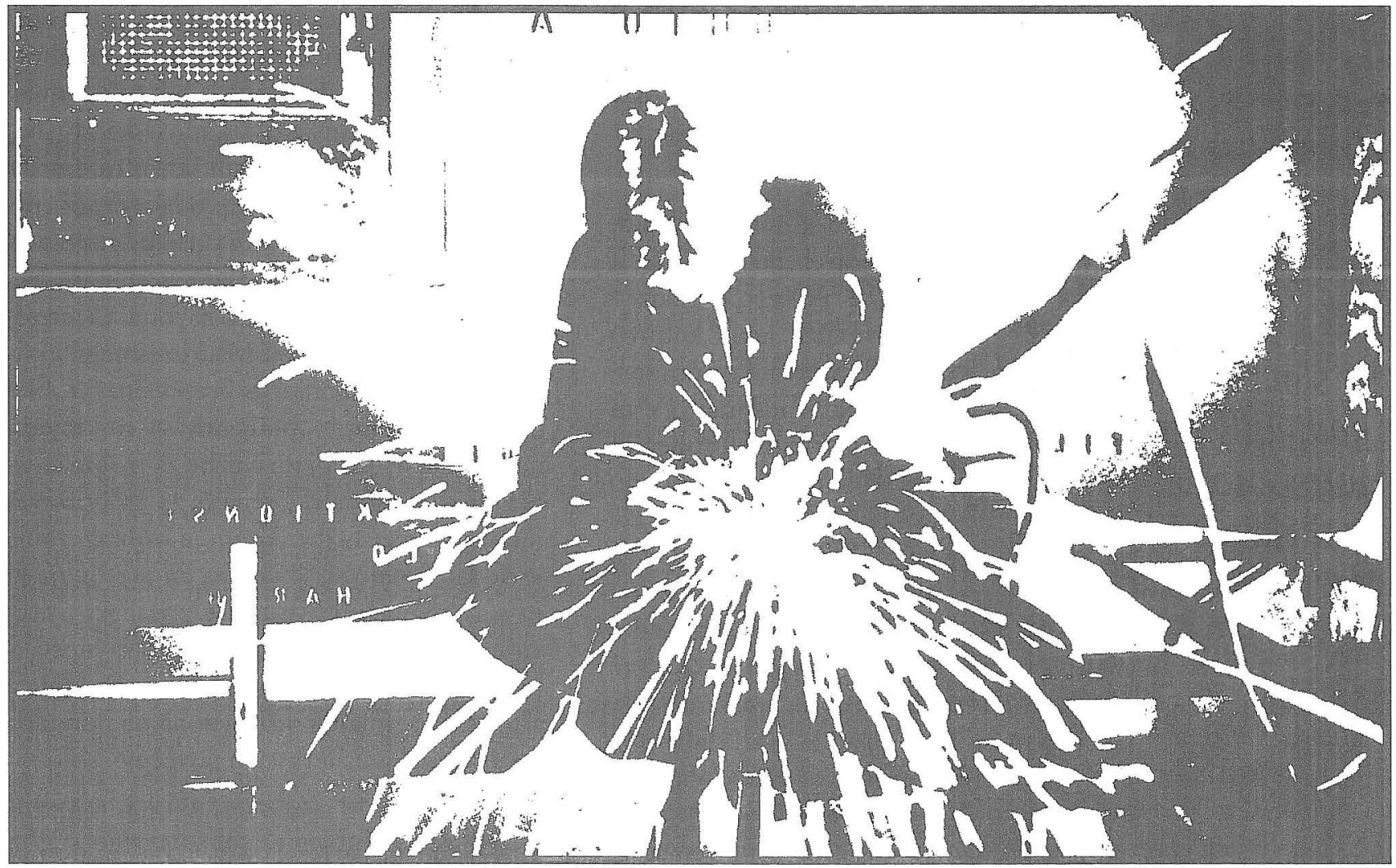

valni programi bodo tudi v prihodnosti po mnenju vprašancev manj aktualni, saj so jih le redko omenjali kot prednostne pri oblikovanju izobraževalne strategije.

Analiza celotne razdelitve odgovorov v raziskavi nakazuje, da so "organizatorji« izobraževanja $\mathrm{v}$ podjetjih podpirali predvsem programe izobraževanja in usposabljanja za delo, tem pa sledijo programi za pridobitev izobrazbe. Kljub nekaterim pozitivnim poskusom, da bi povečali usposobljenost zaposlenih za opravljanje neposrednega dela, pa odgovori kažejo, da v obravnavanih podjetjih pri ustvarjanju celotne izobraževalne strategije še ni dovolj razvito razmišljanje o vpeljevanju programov, ki bi ustrezali dolgoročni razvojni politiki. Posledica tega je, da $\mathrm{v}$ prakso niso dovolj vpeljani programi splošnega izobraževanja, ki dopolnjujejo sistem celotnega izobraževanja in so namenjeni podjetjem, da bi se lahko razvijala konti- nuirano, trajno (sustainable development), učinkovito in smotrno.

Glede mreže ustanov in institucionalnega urejanja izobraževalne dejavnosti se v Sloveniji za zdaj kot najpogostejši ponudniki izobraževanja in usposabljanja pojavljajo podjetja sama, institucije za izobraževanje odraslih ter šole različnih stopenj, najredkeje pa medpanožna izobraževalna središča, območna izobraževalna središča in izobraževanje v tujini, ki se le izjemoma navaja kot možnost pri reševanju problemov usposabljanja in izpopolnjevanja $v$ gospodarstvu. To pomeni, da so podjetja $\mathrm{v}$ svojih razvojnih načrtih zanemarila možnosti za izobraževanje/usposabljanje na nekaterih pomembnih ravneh, še posebej na regionalni, panožni, medpanožni ravni in $\mathrm{v}$ drugih gospodarskih organizacijah. To je po eni strani posledica preslabe uveljavljenosti teh ustanov v državi ali nezadostnega širjenja in ponudbe njiho- 
vih izobraževalnih programov, slabe kakovosti ali previsokih cen, po drugi strani pa preslabe seznanjenosti zaposlenih $\mathrm{z}$ izobraževalnimi možnostmi, ki jih te ustanove ponujajo.

Ustreznejša in nujnejša institucionalna ureditev zadovoljevanja potreb po izobraževanju in usposabljanju je precej povezana $z$

V slovenskih podjetjif pogrešamo uvrščnost izobraževanja $v$ razvojne načrte. ocenjevanjem ravni kakovosti izobraževanja posameznih oblik in institucij. $\mathrm{V}$ raziskavi je bila na primer razmeroma dobro (pozitivno) ocenjena kakovost izobraževanja in usposabljanja $\mathrm{v}$ lastnem podjetju, šolah različnih stopenj in drugih institucijah za izobraževanje odraslih (ljudske univerze, družbeni in zasebna izobraževalna središča ipd.). Kot nezadostna ali slaba pa je bila ocenjena kakovost izobraževanja in usposabljanja $v$ drugih gospodarskih organizacijah. Pri ugotavljanju kakovosti so se anketirani izredno težko odločali o izbiri izobraževanja $\mathrm{v}$ regionalnem, medpanožnem izobraževalnem središču, $v$ organizacijah drugje v Sloveniji in tujini. Ta neodločnost je najbrž deloma posledica zaprtosti podjetja, pa tudi gospodarnosti in varčevanja, zaradi česar podjetja večinoma sama pripravijo in izpeljejo izobraževanje. Drugi vzrok za neodločnost je nedvomno nezadostna seznanjenost oseb, odgovornih za izobraževanje, $\mathrm{s}$ kakovostjo izpeljave te dejavnosti v drugih institucijah zaradi pomanjkanja povratnih informacij in nesodelovanje $z$ institucijami zunaj gospodarstva. To opozarja, da lahko $z$ ustreznejšim organiziranjem izobraževanja $\mathrm{v}$ podjetjih lahko pričakujemo boljše spremljanje poteka učenja ter vrednotenje dosežkov izobraževanja, ne le tistega, ki poteka $\mathrm{v}$ lastnem podjetju, temveč tudi drugje.

Organizacijsko in kadrovsko je funkcija izobraževanja $\mathrm{v}$ podjetjih bolj slabo urejena.
Prevladuje namreč mnenje, da so za spremljanje, vrednotenje ter organiziranje izobraževanja in usposabljanja $v$ podjetjih najpogosteje odgovorni vodja kadrovske službe, vodja splošnega sektorja in vodja celotnega podjetja. Res pa je, da je ta odgovornost pri usklajevanju izobraževanja precej povezana z značilnostmi podjetij (velikost, panožna pripadnost) in tudi $z$ institucionalno urejenostjo te problematike. Med institucionalnimi rešitvami urejanja izobraževalne problematike $\mathrm{v}$ izbranih podjetjih so anketirani najpogosteje omenjali: službe za izobraževanje (sektor, oddelek, referat za izobraževanje) ali druge službe, ki jim je izobraževanje le dodatna naloga. Videti je, da se stopnja in raven organiziranosti ter še posebej institucionaliziranosti izobraževalne dejavnosti $\mathrm{v}$ podjetjih $\mathrm{v}$ primerjavi s prejšnjim obdobjem zmanjšuje, zunanja institucionalna ponudba pa se na nekaterih ravneh povečuje.

Tudi uvrščenost izobraževanja $\mathrm{v}$ razvojne načrte in vrednotenje izobraževanja $v$ gos-

Vrednotenje izobraževanja je najbolje ocenjeno na podjetníski ravni in najslabše na občinski; to poneni, da obcine poleg dokajšnje avtonomije in kompetenc, ki Th imajo na izobraževalnem področju, śe ne posegajo dovolj v razvijanje izobrażevalne politike v gospodarstvu. Nerešeno ostane torej vprasanje, ali se bo v prihodnje vloga obcin in nekoliko tudi panog spremenila, povečala ali pa podjetja pri načrtovanju izobraževalne strategije ne bodo raćunala na pomoé primarnih družbenih struktur. Vsekakor zdajšnje stanje vključenosti, pa tudi vrednotenja izobraževanja, $v$ načrte in politiko razvoja kot bistvenega dejavnika gospodarskega razvoja ni ravin v skladu z evropskimi usmeritvami, v katerih je izobraževalna problematika praviloma uvrśčcena v naćrte lokalnih skupnosti. 
podarstvu nista, kakor kažejo izsledki raziskave, zadostna, vsaj ne na vseh ravneh (država, občina, panoga, podjetje). Prevladujejo "sredinski« in ponekod tudi negativni odgovori na vprašanja o potrebi glede uvrščenosti izobraževanja $v$ razvojne načrte in tudi glede vrednotenja izobraževanja ter usposabljanja. Pri tem pa vendarle lahko sklepamo, da so vprašani najbolj zadovoljni $\mathrm{z}$ vključenostjo izobraževanja $v$ podjetju, sledita raven države in panoge, najmanj pa $z$ njegovo vključenostjo na ravni občine.

To, da nekatera podjetja danes premalo uvrščajo izobraževanje in usposabljanje $\mathrm{v}$ svoje načrte razvoja in namenjajo manj pozornosti izobraževanju in usposabljanju, je delno razumljivo, če upoštevamo njihovo povprečno slabo finančno stanje in ozko definirano tržno usmerjenost podjetij, ki si trenutno postavljajo druge cilje, pogosto na račun izobraževanja. Izobraževanje/usposabljanje zavirajo tudi pomanjkanje ustreznih izobraževalnih programov, splošno družbeno ozračje, ki slabo vpliva na to dejavnost, slaba organiziranost in zakonska urejenost ter neustrezna včlenjenost izobraževanja $\mathrm{v}$ načrte razvoja občine in države. Za izboljšanje stanja in ustvarjanje boljših možnosti za opravljanje te dejavnosti so vprašani predlagali: razvijanje ustreznejše politike izobraževanja zaposlenih, višje vrednotenje te dejavnosti, učinkovitejše analiziranje in ugotavljanje potreb po izobraževanju ter usposabljanju, spodbujanje povezovanja med izobraževanjem in zaposlovanjem, boljše financiranje ali sofinanciranje te dejavnosti v podjetju, občini, panogi in državi, povečanje možnosti za vključevanje zaposlenih $\mathrm{v}$ izobraževanje ipd. Vsekakor pa se pri tem postavlja načelno vprašanje, ali se izobraževanje v gospodarstvu še zmeraj obravnava kot dejavnik in sredstvo razvoja ali kot strošek poslovanja.

$\mathrm{V}$ raziskavi smo skušali odgovoriti tudi na to, kako se na gospodarske in druge spremembe odzivajo različni tipi podjetij ali podjetja različne velikosti, lastninske strukture, panožne in regionalne pripadnosti.

Ugotovili smo pomembno povezanost med velikostjo organizacije in načinom organiziranja izobraževalne dejavnosti, oblikami izobraževanja in osebo, odgovorno za izobraževanje v podjetju. Večje organizacije se pri organiziranju izobraževanja bolj nagibajo $\mathrm{k}$ notranjim rešitvam predvsem $\mathrm{z}$ (ponovnim) ustanavljanjem izobraževalnega središča v podjetju. Zaposleni v manjših podjetjih pa pogosteje pridobivajo znanje $\mathrm{v}$ institucijah za izobraževanje zunaj podjetja.

Neenaka usmerjenost podjetij obravnavanih gospodarskih panog je najvidnejša pri organiziranju možnosti za izobraževanje v obliki izobraževalne službe ali središc. v podjetju oziroma skupnega izobraževalnega središča (službe) v panogi, medpanožnega in regionalnega izobraževalnega središča. $\mathrm{Za}$ posleni $v$ podjetjih primarnega sektorja se bolj zavzemajo za to, da bi bilo organizirano izobraževanje $v$ regionalnem sredisču, zaposleni v podjetjith sekundarnega, terciarnega in kvartarnega sektorja pa za ustanavljanje izobraževalnega središ̌̌a (službe) v podjetju. Vprašanje je, ali se podjetja v sekundarni, terciarni in kvartarni dejavnosti nagibajo $\mathrm{k}$ ustanavljanju središča (službe) v lastnem podjetju zaradi boliših možnosti za uresničevanje te dejavnosti v lastnem podjetju ali zato, ker zaradi tekmovalnosti in drugih vzrokov niso bila pripravljena na sodelovanje $\mathrm{z}$ drugimi organizacijami tega sektorja.

Po kazalnikih, ki smo jih dobili, obstaja tudi povezanost med regionalno pripadnostjo podjetja in načinom organiziranja izobraževanja. Podjetjem v regijah, ki so bolj oddaljene od republiškega središča, je več do ustanavljanja regionalnega središča, in nasprotno, podjetja $\mathrm{v}$ republiških središčih pri reševanju izobraževalne problematike ne računajo toliko na regionalna središča.

S stališča celotnega družbenega razvoja nas je izredno zanimalo, kako se odzivajo na novo nastale možnosti organizacije $v$ zasebni in 
mešani lasti ter kakšno izobraževalno strategijo oblikujejo pri tem. Izidi so nas presenetili, saj smo ugotovili, da na novo nastale zasebne organizacije in organizacije $\mathrm{z}$ mešano lastninsko sestavo v primerjavi z državnimi javnimi nimajo večjih težav pri organiziranju izobraževanja in njegovega uvrščanja med druge potrebe. Pomembno je povedati, da so bili vprašani iz zasebnih podjetij manj kritični do družbenih, panožnih in občinskih ovir. To pomeni, da celotno družbeno ozračje dovolj podpira razvoj izobraževalne dejavnosti v teh organizacijah ali da se te organizacije opirajo bolj na svoje moči.

\section{OBLIKOVANJE MODELOV}

Ker je bila zdajšnja organiziranost izobraževanja $\mathrm{v}$ gospodarstvu marsikdaj predmet kritike in nezadovoljstva, smo v nalogi na podlagi zbranih mnenj in stališč predložili modele, ki bi, izhajajoč iz lastnosti obravnavanih podjetij, najbolj ustrezali zdajšnjemu stanju in razvojnim usmeritvam v družbi in gospodarstvu.

\section{$\mathrm{V}$ svetu so razvili štiri modele organiziranosti izobraževanja $v$ gospodarstvu.}

Interni model izobraževanja $\mathrm{v}$ gospodarstvu predpostavlja, da poteka izobraževanje predvsem v organizacijah, $\mathrm{v}$ katerih zaposleni delajo. Najprimernejši je za velika podjetja, ki imajo svoja izobraževalna središča, v katerih poteka večina dejavnosti usposabljanja in izpopolnjevanja vseh zaposlenih, še posebej tistih z nižjo ali neustrezno kvalifikacijo. Le majhen delež znanja in spretnosti pridobivajo zaposleni zunaj podjetij: udeležujejo se izobraževanja po programih za pridobivanje izobrazbe, ki potekajo praviloma $\mathrm{v}$ šolah različnih stopenj, in pridobivajo visoko specializirano znanje. $V$ začetnem obdobju tržnega gospodarstva, za katero sta skimi subjekti in njihova relativna zaprtost, ima tak način pridobivanja znanja nekatere prednosti pri izboljševanju znanja in izkušenj v podjetju, še posebej, če se izobraževalni center $\mathrm{v}$ podjetju povezuje $\mathrm{z}$ razvojnim. Interni model organiziranosti izobraževanja zaposlenih se srečuje $\mathrm{v}$ vseh preučevanih evropskih državah, največ pa na Danskem, v Nemčiji, Veliki Britaniji in Italiji.

Interni model organiziranja izobraževanja posebej spodbuja tekmovalno ozračje velikih podjetij, vendar ga je težko izpeljati v majhnih in srednje velikih podjetjih, ki si težko privoščijo ustanavljanje izobraževalnih središč in imajo slabo kadrovsko sestavo za uresničevanje takšnih nalog. Takih podjetij pa je v Sloveniji zelo veliko. To pa pomeni, da bo interni model v Sloveniji aktualen, čeprav sta njegov razvoj in uporaba nekoliko omejena na določeno število večjih podjetij.

Regionalni (prostorski) model izobraževanja zaposlenih $\mathrm{v}$ gospodarstvu prevladuje predvsem $\mathrm{v}$ državah, kjer so podjetja prostorsko zelo decentralizirana, in $\mathrm{v}$ tistih, $\mathrm{ki}$ imajo veliko manjših podjetij. Zaradi oddaljenosti podjetij od republiškega središča ta model zahteva in spodbuja decentralizacijo izobraževalnih institucij v prostoru. Regionalni model zajema heterogene tipe izobraževalnih institucij (ljudske univerze, društva, regionalna izobraževalna središča, šole na različnih ravneh, združenja ali druga podjetja, ki delujejo $\mathrm{v}$ regiji), ki so $\mathrm{v}$ istih regijah, kjer so podjetja. Prednost modela je ta, da omogoča zaposlenim manjšo odsotnost $\mathrm{z}$ dela med izobraževanjem, sprejemljiv pa bo za podjetja različnih velikosti in panog. Pomanjkljivosti modela so sorazmerna zaprtost, osamelost in nepovezanost z drugimi regijami, neustreznost za zadovoljevanje tistih potreb po izobraževanju, ki so specifične in jim je mogoče zadostiti le v izobraževalnih institucijah, ki ponujajo višjo specializacijo, in $v$ tujini. 
Regionalna razdelitev institucij pri zadovoljevanju potreb po izobraževanju in usposabljanju pripomore $\mathrm{k}$ bolj usklajenemu regionalnemu razvoju. Model je najbolj razširjen v tistih državah (Kanada, Švedska, Italija), kjer je zaradi velike oddaljenosti od državnega središča prostorska mobilnost delovne sile zmanjšana, in v državah, ki se enakomerneje prostorsko razvijajo (na primer danska AMU središča ali belgijska regionalna združenja FOREM). Izidi kažejo, da ta model ne bo v bližnji prihodnosti v Sloveniji dovolj izrabljen, bodisi zaradi nezadostno razvite mreže regionalnih izobraževalnih ustanov bodisi zaradi majhnosti slovenskega prostora, ki omogoča večji dostop do vseh izobraževalnih središč.

Panožni ali medpanožni model izobraževanja prevladuje v gospodarskih sistemih, ki ustvarjajo svoje izobraževalne institucije na podlagi povezovanja in sodelovanja podjetij v eni ali več panogah. Ta model je pogost način organiziranosti izobraževanja v Belgiji, Nemčiji, Italiji in Veliki Britaniji. V njem prevladujejo panožne, medpanožne in tudi druge institucije, ki ponujajo usposabljanje in izpopolnjevanje $\mathrm{z}$ določenega področja $\mathrm{v}$ gospodarstvu. Panožni model je namenjen vsem zaposlenim v panogi in odpira prostor majhnim, srednjim in velikim podjetjem, pa tudi tistim, ki so $\mathrm{v}$ različnih regijah. Izidi raziskave so pokazali, da se bodo za izbiro panožnega modela pogosteje odločala podjetja $\mathrm{v}$ primarni in sekundarni bazični industriji in da ga je treba razširjati ter bolj uveljavljati v praksi.

Uporaba tega modela je za zdaj delno omejena zaradi prevelike specializacije institucij v eni panogi, slabše ponudbe splošnih programov in tistih za pridobitev izobrazbe ter delno zaradi prostorske oddaljenosti panožnih izobraževalnih središč, ki združujejo nekaj regij.

Mrežni model izobraževanja temelji na možnostih za medsebojno povezovanje velikih

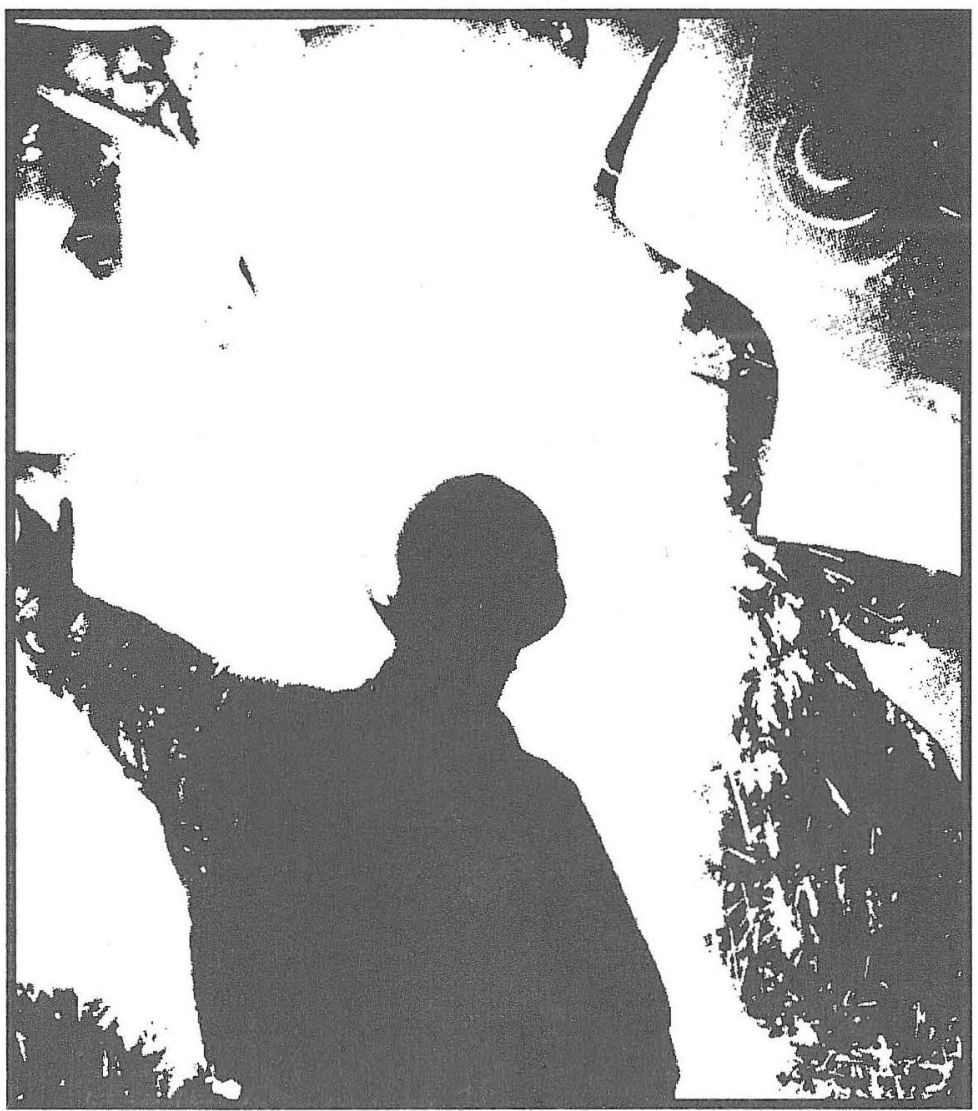

in tudi srednje velikih ter majhnih podjetij. Mrežni model izobraževanja in usposabljanja kombinira povezovanje na regionalni, panožni in tudi medpanožni ravni, zajema pa tudi nekatere oblike internega izobraževanja in usposabljanja, ki poteka $\mathrm{v}$ samih podjetjih in postaja bolj odprto in prožno za potrebe drugih. Ta model zahteva sodelovanje pri pripravljanju izobraževalnih programov na vseh ravneh (na primer pri pripravi programov na ljudskih univerzah, šolah različnih stopenj, v panožnih, medpanožnih in regionalnih izobraževalnih središčih, ne zanemarja pa tudi manj specializiranih institucij, kot so društva, združenja). Mrežni model se je zelo uspešno uveljavil v svetu pri nizozemskih pridelovalcih cvetja, švicarskih izdelovalcih ur, v Belgiji pa je ta model širše uveljavljen v naftni, lesni, gradbeni in kemični industriji. V Sloveniji bo ta model spre- 


\section{Shema modelov izobraževalne organiziranosti v slovenskem gospodarstvu}

Prostorsko načelo

država

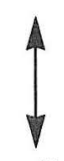

regija

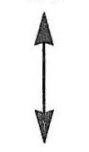

občina
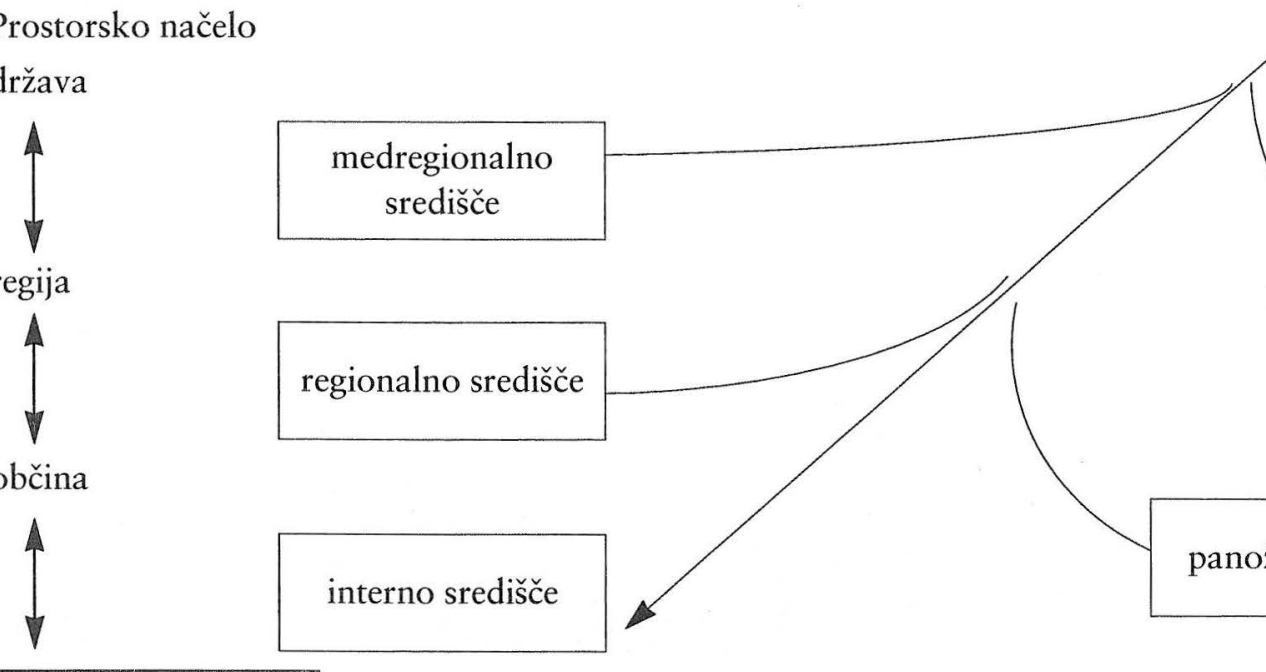
medpanožno središče

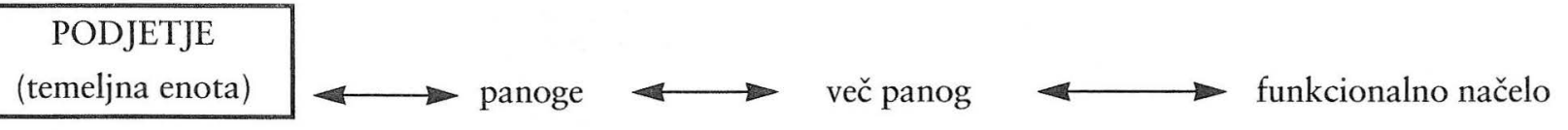

jemljiv za podjetja vseh panog, najbolj pa za tista v kvartarni dejavnosti, za podjetja vseh velikosti, objektivno pa se lahko uresničuje $\mathrm{v}$ gospodarsko razvitih območjih z že prestrukturirano industrijo.

\section{SKLEP}

Iz analize raziskovalnih rezultatov lahko sklepamo, da so hipotetično zastavljeni modeli organiziranosti izobraževanja v gospodarstvu sprejemljivi tudi $v$ slovenskih razmerah. Dejansko pa jih ne zasledimo $v$ obliki čistega tipa, temveč se dopolnjujejo, izmenjujejo, med seboj povezujejo, lahko pa tudi izključujejo, kar pomeni, da podjetja, ki se odločijo za izbiro enega tipa izobraževalnih institucij, redko uporabljajo tudi institucije drugih tipov. Po podatkih, ki smo jih dobili, se da ugotoviti, da pri danih modelih prevladujejo nekateri tipi podjetij.

Ta izid je razumljiv s stališča slabših možnosti podjetij, da organizirajo visokospecializi- rane programe usposabljanja, ki bi zadovoljevali tudi zahteve visokokvalificiranih in izobraženih delavcev. Ti zato izbirajo izobraževalne programe $\mathrm{v}$ nekaterih bolj specializiranih ustanovah doma in $\mathrm{v}$ tujini. Po drugi strani ta izid ni v skladu s filozofijo vseživljenjskega učenja, po kateri se pridobiva novo znanje in spretnosti skozi ves delovni proces "learning by doing «. Regionalni model je manj razširjen $v$ primerjavi $z$ drugimi, bodisi zaradi neenakomerno razvite

Interni model organiziranosti izobraževanja je pogost način usposabljanja zaposlenih v velikih sistemih, ki imajo več sredstev in možnosti, da vlagajo v svojo izobraževalno dejavnost, $v$ podjetjih $z$ ustrezno kadrovsko sestavo in tradicijo. Presenetlivo je tudi to, da je bil interni model usposabljanja pripisan predvsem nizko izobraženim delavcem in le redko tistim podjetjem, ki zaposlujejo visoko izobraženo in kvalíicirano delovno silo. 
Regionalna razdelitev institucij pri zadovoljevanju potreb po izobraževanju in usposabljanju pripomore $\mathrm{k}$ bolj usklajenemu regionalnemu razvoju. Model je najbolj razširjen v tistih državah (Kanada, Švedska, Italija), kjer je zaradi velike oddaljenosti od državnega središča prostorska mobilnost delovne sile zmanjšana, in v državah, ki se enakomerneje prostorsko razvijajo (na primer danska AMU središča ali belgijska regionalna združenja FOREM). Izidi kažejo, da ta model ne bo v bližnji prihodnosti v Sloveniji dovolj izrabljen, bodisi zaradi nezadostno razvite mreže regionalnih izobraževalnih ustanov bodisi zaradi majhnosti slovenskega prostora, ki omogoča večji dostop do vseh izobraževalnih središč.

Panožni ali medpanožni model izobraževanja prevladuje v gospodarskih sistemih, ki ustvarjajo svoje izobraževalne institucije na podlagi povezovanja in sodelovanja podjetij v eni ali več panogah. Ta model je pogost način organiziranosti izobraževanja v Belgiji, Nemčiji, Italiji in Veliki Britaniji. V njem prevladujejo panožne, medpanožne in tudi druge institucije, ki ponujajo usposabljanje in izpopolnjevanje $\mathrm{z}$ določenega področja $\mathrm{v}$ gospodarstvu. Panožni model je namenjen vsem zaposlenim v panogi in odpira prostor majhnim, srednjim in velikim podjetjem, pa tudi tistim, ki so $\mathrm{v}$ različnih regijah. Izidi raziskave so pokazali, da se bodo za izbiro panožnega modela pogosteje odločala podjetja $\mathrm{v}$ primarni in sekundarni bazični industriji in da ga je treba razširjati ter bolj uveljavljati v praksi.

Uporaba tega modela je za zdaj delno omejena zaradi prevelike specializacije institucij v eni panogi, slabše ponudbe splošnih programov in tistih za pridobitev izobrazbe ter delno zaradi prostorske oddaljenosti panožnih izobraževalnih središč, ki združujejo nekaj regij.

Mrežni model izobraževanja temelji na možnostih za medsebojno povezovanje velikih

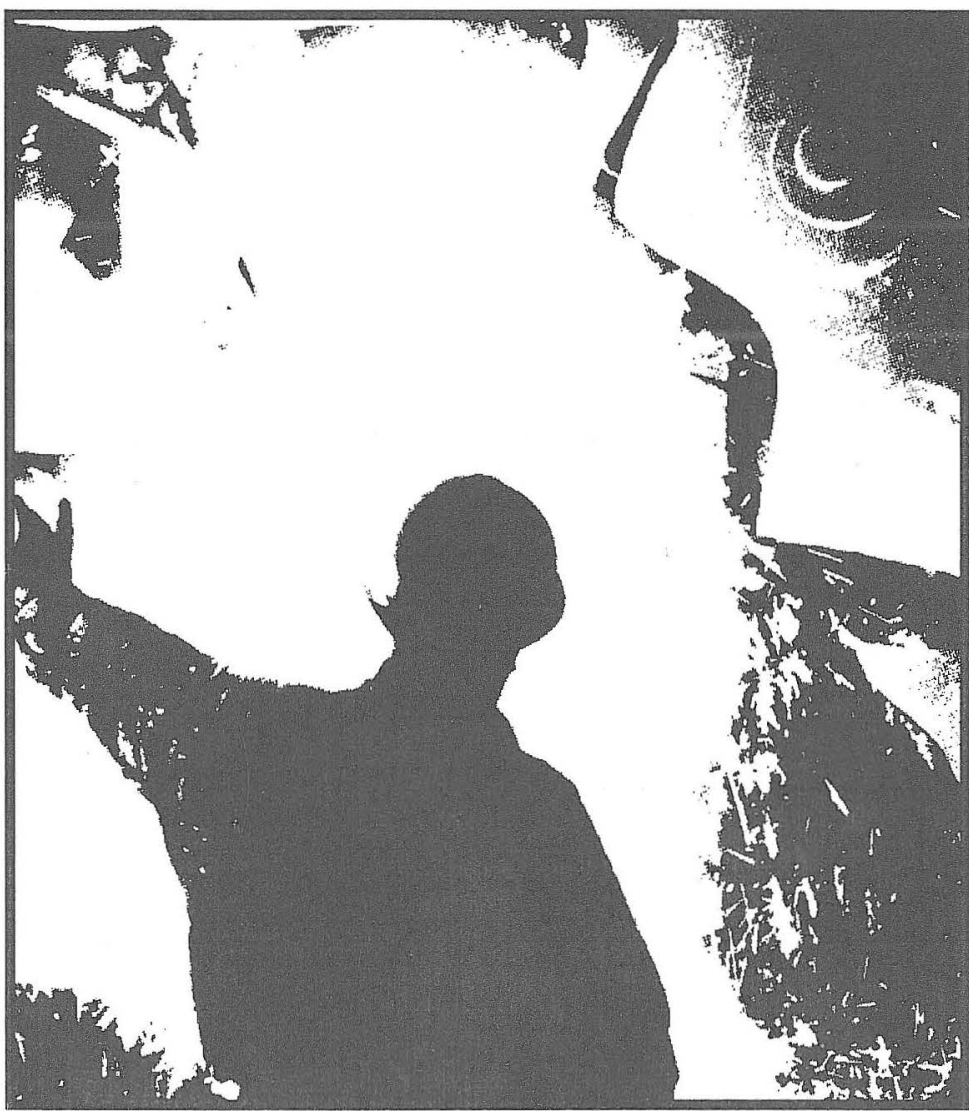

in tudi srednje velikih ter majhnih podjetij. Mrežni model izobraževanja in usposabljanja kombinira povezovanje na regionalni, panožni in tudi medpanožni ravni, zajema pa tudi nekatere oblike internega izobraževanja in usposabljanja, ki poteka v samih podjetjih in postaja bolj odprto in prožno za potrebe drugih. Ta model zahteva sodelovanje pri pripravljanju izobraževalnih programov na vseh ravneh (na primer pri pripravi programov na ljudskih univerzah, šolah različnih stopenj, v panožnih, medpanožnih in regionalnih izobraževalnih središčih, ne zanemarja pa tudi manj specializiranih institucij, kot so društva, združenja). Mrežni model se je zelo uspešno uveljavil v svetu pri nizozemskih pridelovalcih cvetja, švicarskih izdelovalcih ur, v Belgiji pa je ta model širše uveljavljen v naftni, lesni, gradbeni in kemični industriji. V Sloveniji bo ta model spre- 


\section{Shema modelov izobraževalne organiziranosti v slovenskem gospodarstvu}

Prostorsko načelo

država

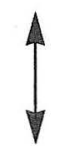

regija

$\uparrow$

občina
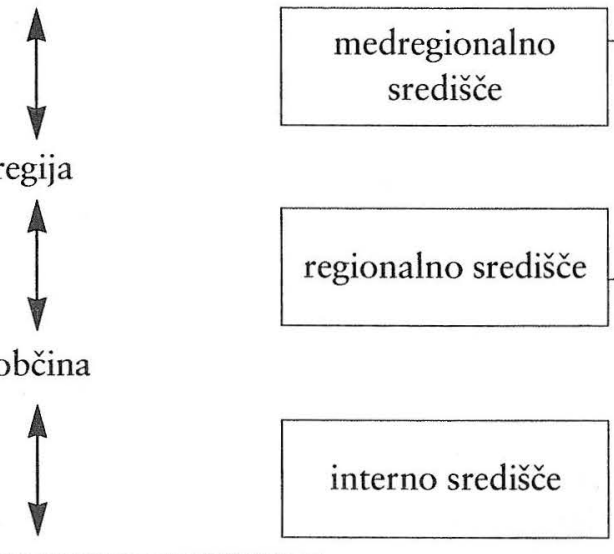

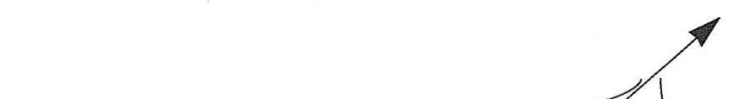

PODJETJE

(temeljna enota)

panoge

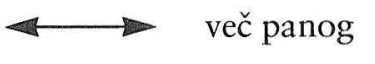

funkcionalno načelo

jemljiv za podjetja vseh panog, najbolj pa za tista v kvartarni dejavnosti, za podjetja vseh velikosti, objektivno pa se lahko uresničuje v gospodarsko razvitih območjih z že prestrukturirano industrijo.

\section{SKLEP}

Iz analize raziskovalnih rezultatov lahko sklepamo, da so hipotetično zastavljeni modeli organiziranosti izobraževanja $\mathrm{v}$ gospodarstvu sprejemljivi tudi $\mathrm{v}$ slovenskih razmerah. Dejansko pa jih ne zasledimo v obliki čistega tipa, temveč se dopolnjujejo, izmenjujejo, med seboj povezujejo, lahko pa tudi izključujejo, kar pomeni, da podjetja, ki se odločijo za izbiro enega tipa izobraževalnih institucij, redko uporabljajo tudi institucije drugih tipov. Po podatkih, ki smo jih dobili, se da ugotoviti, da pri danih modelih prevladujejo nekateri tipi podjetij. Ta izid je razumljiv s stalisča slabših možnosti podjetij, da organizirajo visokospecializi-

rane programe usposabljanja, ki bi zadovoljevali tudi zahteve visokokvalificiranih in izobraženih delavcev. Ti zato izbirajo izobraževalne programe $\mathrm{v}$ nekaterih bolj specializiranih ustanovah doma in $\mathrm{v}$ tujini. Po drugi strani ta izid ni v skladu s filozofijo vseživljenjskega učenja, po kateri se pridobiva novo znanje in spretnosti skozi ves dclovni proces »learning by doing «. Regionalni model je manj razširjen $\mathrm{v}$ primerjavi $\mathrm{z}$ drugimi, bodisi zaradi neenakomerno razvite

Interni model organiziranosti izobraževanja je pogost način usposabljanja zaposlenih $v$ velikih sistemih, ki imajo več sredstev in možnosti, da vlagajo $v$ svojo izobraževalno dejavnost, $v$ podjetjih $\mathrm{z}$ ustrezno kadrovsko sestavo in tradicijo. Presenetlivo je tudi to, da je bil interni model usposabljanja pripisan predvsem nizko izobraženim delavcem in le redko tistim podjetjem, ki zaposlujejo visoko izobraženo in kvalificirano delovno silo. 
mreže izobraževalnih institucij v slovenskem prostoru bodisi zaradi majhnosti slovenske države. To omogoča večjo mobilnost delovne sile ali lažji in hitrejši dostop tudi do vseh izobraževalnih ustanov v državi. Za izbiro panožnega ali medpanožnega modela naj bi se večinoma odločala podjetja v primarni in sekundarni bazični industriji, ne glede na to, ali so majhna, srednja ali velika. Toda uspešnost in uveljavljanje tega modela bosta $\mathrm{v}$ prihodnje precej povezana $\mathrm{z}$ delom panožnih združenj ter z njihovo pripravljenostjo, da bi tudi materialno podpirali delo panožnih in medpanožnih izobraževalnih središč. Intervjuvani $\mathrm{v}$ prihodnje najbolj računajo na uporabnost mrežnega modela. M. Jaklič je pred kratkim razložil delovanje mrežnega koncepta, za katerega pravi, da gre za mrežno povezovanje, ki temelji na neformalnem trgovanju $\mathrm{z}$ znanjem. Takšno trgovanje ne temelji na pogodbeni obveznosti, temveč na načelu »daj - dam «. Tudi v prihodnosti se bosta čedalje bolj upoštevala mrežni koncept in dogajanje na svetovnih trgih. Posamezne značilnosti delovanja teh mrež bodo v prihodnje odvisne od gospodarskih, družbenih in kulturnih norm, ki delujejo v družbi. Te norme pa ne bodo statične, odzivali se bodo na dinamiko gospodarskih, političnih in širše družbenih sprememb.

Predpostavka aktiviranja (uresničevanja) teh modelov pa je nedvomno oblikovanje ustrezne nacionalne in gospodarske strategije ter ureditev tega področja, angažiranje širših finančnih virov za to dejavnost in zagotavljanje ustrezne stimulacije $\mathrm{s}$ strani $\mathrm{dr}$ žave, socialnih partnerjev in še posebej gospodarskih združenj na vseh ravneh, nič manj pa prilagajanje izobraževalne dejavnosti potrebam trga in podjetij.

\section{LITERATURA IN VIRI}

Agenda 2000 (1997). European Commission: Bruselj. Boje, D., Gephart, R., Tojo, J. (1996). Postmodern Ma- nagement and Organisation Theory. SAGE - Publications, London.

Collins, H. (1993). European Vocational Education System. A Guide to Vocational Education and Training in the European Community. Kogan Page, London.

Druker, P. (1993). Managing for the Future: The $1990 \mathrm{~s}$ and Beyond. Truman Taley Books/Plume, New York.

Jaklič, M. (1994). Strateško usmerjanje gospodarstva. Znanstveno in publicistično središče, Zbirka Forum, Ljubljana.

Medveš, Z., Muršak, J. (1993). Poklicno izobraževanje - problemi in perspektive. Slovensko društvo pedagogov, Znanstveni inštitut Filozofske Fakultete, Ljubljana.

Medveš, Z., Muršak, J. (1992). Sistemsko urejanje poklicnega izobraževanja. Slovensko društvo pedagogov, Andragoško društvo Slovenije, Ministrstvo za šolstvo in šport, Ljubljana.

Približevanje Evropi - rast, konkurenčnost in integriranje - strategija gospodarskega razvoja Slovenije (1995) (urednik: Potočnik, J. idr.), Urad Republike Slovenije za makroekonomske analize in razvoj, Ljubljana.

Recommendation on the Development of Adult Education (1976). UNESCO, Addopted by the General Conference at its Nineteenth Session, Nairobi, 26. november. Rubenson, K., Schutze H. (1995). Learning at and through the Workplace (neobjavljeno besedilo - interno gradivo ACS).

Titmus, C. J. (1989). Lifelong Education for Adults: An International Handbook. Pergamon Press, Oxford.

Toffler, A. (1970). Future Shock. Bantham Books. New York.

Trends in Innovation in Continuing Education and Training (1982). CEDEFOP, Berlin.

Vocational Education and Training in Belgium (1996). (urednika: Adams, M., Clarke, A.), CEDEFOP, Bruselj. Vocational Education and Training in Denmark (1995). (urednik: Soren P. Nielsen), CEDEFOP, Berlin. Vocational Education and Training in France (1994). (urednik: Williems, J. P.), CEDEFOP, Paris.

Vocational Education and Training in Italy (1995), (urednik: Fressura, N.), CEDEFOP, Solun.

Vocational Education and Training in Luxembourg (1994), (uredniki: Poos J. F., Tagliaferri, J. K.), CEDEFOP, Berlin.

Vocational Education and Training in Netherlands (1994). (urednika: Romken, L., Visser, K.), CEDEFOP, Berlin.

Vocational Education and Training in the Federal Republic of Germany (1982) (urednik: Munch, J.), CEDEFOP, Berlin.

Vocational Education and Training in Portugal (1996) (urednik: Grilo, M.), CEDEFOP, Bruselj.

Vocational Education and Training in the United Kingdom (1993) (urednik: Twining, J.), CEDEFOP, Berlin. 